\title{
ЗМІНИ ПОКАЗНИКІВ АНТИОКСИДАНТНО-ПРООКСИДАНТНОЇ СИСТЕМИ В ТКАНИНІ ЛЕГЕНЬ ЗА УМОВ ТРАВМИ ОРГАНІВ ЧЕРЕВНОЇ ПОРОЖНИНИ, ГІПОВОЛЕМІЧНОГО ШОКУ ТА РЕПЕРФУЗІЇ НИЖНІХ КІНЦІВОК В ЕКСПЕРИМЕНТІ
}

Вступ. У статті наведено результати експериментального дослідження, під час якого вивчали вплив реперфузії нижніх кінцівок на зміни показників антиоксидантно-прооксидантної системи у тканині легень при закритій травмі органів черевної порожнини та масивній зовнішній крововтраті. Вони показали, що реперфузія нижніх кінцівок у поєднанні з модельованими травмами викликає значну активацію системи пероксидного окиснення ліпідів протягом 7-ми днів посттравматичного періоду.

Мета дослідження - вивчити зміни антиоксидантно-прооксидантної системи у тканині легень на моделі поєднаної травми органів черевної порожнини, гіповолемічного шоку та реперфузії нижніх кінцівок.

Методи дослідження. Експеримент проведено на 80-ти нелінійних щурах-самцях масою 190-220 г. У дослідних групах було змодельовано реперсрузію нижніх кінцівок у поєднанні із закритою травмою органів черевної порожнини на тлі масивної крововтрати та проаналізовано динаміку змін показників ТБК-активних продуктів і каталази. На основі цих даних розраховували антиоксидантно-прооксидантний індекс. Достовірність відмінностей між контрольною та дослідними групами оцінювали з використанням непараметричного критерію Манна - Уітні.

Результати й обговорення. Результати аналізу змін системи пероксидного окиснення ліпідів у дослідних групах свідчать про те, що накладання кровоспинних джгутів на обидві нижні кінцівки піддослідних тварин викликало значну активацію цієї системи протягом 7-ми днів після моделювання травми. Поєднання закритої травми органів черевної порожнини з масивною крововтратою і реперфузією кінцівки призвело до виникнення тривалого оксидативного стресу, а зниження антиоксидантно-прооксидантного індексу - до виснаження антиоксидантних механізмів.

Висновок. Накладання кровоспинних джгутів на дві нижні кінцівки на 2 год викликає тривалу активацію системи ліпідної пероксидації, що підтверджується статистично достовірним $(p<0,05)$ збільшенням вмісту ТБК-активних продуктів пероксидного окиснення ліпідів з максимумом через 3 доби.

КЛЮЧОВІ СЛОВА: реперфузія; експеримент; легені; пероксидне окиснення ліпідів; поєднана травма; масивна крововтрата.

ВСТУП. Поєднана травма залишається актуальною проблемою медицини, оскільки є основною причиною смерті в постраждалих працездатного віку [1, 2]. До основних причин смерті серед травмованих на догоспітальному етапі належить масивна крововтрата [3]. В останні роки досягнуто значного прогресу в наданні допомоги постраждалим 3 масивною крововтратою завдяки широкому впровадженню засобів для зупинки кровотечі, зокрема джгутів $[4,5]$.

Відомо, що накладання джгутів терміном на 2 год є безпечним, однак може викликати розвиток ішемії-реперфузії та активацію системи пероксидного окиснення ліпідів (ПОЛ) [6-8]. Дослідження показали, що у разі відновлення (с) О. В. Федосєєва, 2020. кровопостачання виникає мультифакторне ураження як ішемізованих, так і віддалених тканин.

3 іншого боку, є значний ризик розвитку в постраждалих з поєднаною травмою синдрому поліорганної недостатності (СПОН), що виникає на фоні шоку в процесі реалізації синдрому системної запальної відповіді. Частота розвитку СПОН при поєднаній травмі становить понад 80 \% та супроводжується високою летальністю 30-85 \% [9-11]. Відомо, що закономірність його розвитку, послідовність фуункціональних органних розладів, тяжкість прояву визначаються як характером ушкоджень, так і реактивністю організму. Найпершим "органом-мішенню" в патологічному ланцюзі є легені, фрактично леге- 
ні - pacemaker СПОН [12-14]. Патологічні зміни з боку фрункції легень залишаються важливим фрактором високої смертності в постраждалих після отримання поєднаної травми. Так, в одному з досліджень при розвитку гострого респіраторного дистрес-синдрому смертність становила від 34,9 до 46,1 \% [15]. Особливо важливим є питання щодо розвитку змін з боку легень у постраждалих з поєднаною травмою та масивною крововтратою, оскільки масивне переливання інсузійних розчинів може бути фрактором виникнення змін 3 боку легеневої тканини. Однак залишаються недостатньо вивченими фрактори ризику і прогнози стосовно окремих складових СПОН.

Зважаючи на вищесказане, в цьому експериментальному дослідженні було вивчено вплив реперфузії нижніх кінцівок на розвиток системних змін при поєднаній травмі.

Мета дослідження - вивчити зміни антиоксидантно-прооксидантної системи у тканині легень на моделі поєднаної травми органів черевної порожнини, гіповолемічного шоку та реперфузії нижніх кінцівок.

МЕТОДИДОСЛІДЖЕННЯ. 3 метою реалізації поставленої мети було проведено експериментальне дослідження на 80-ти нелінійних щурах-самцях масою 190-220 г. Усіх тварин поділили на контрольну (КГ) і три дослідних групи (ГД) (по 8 щурів у кожній).

Тваринам 1-ї дослідної групи (ГД-1) було змодельовано реперфузію нижніх кінцівок: під тіопентал-натрієвим знеболюванням (40 мг-к $\left.{ }^{-1}\right)$ проксимально на ліві лапки накладали кровоспинний джгут терміном на 120 хв. Для цього застосовували еластичну смужку джгута "SWAT-T" (США) шириною 10 мм, що відповідала ширині джгута при накладанні на стегно дорослій людині. Джгут затягували відповідно до нанесеного на нього індикатора ефеектвного тиску. Кровоспинний джгут накладали терміном на 2 год 3 метою моделювання ішемічно-реперфузійного синдрому.

щурам 2-ї дослідної групи (ГД-2) було змодельовано поєднану травму органів черевної порожнини: під тіопентал-натрієвим знеболюванням (40 мг $\left.\cdot \Gamma^{-1}\right)$ тварині наносили два дозованих удари в ділянку черевної порожнини за допомогою спеціального пристрою (силу нанесення ударів розраховували таким чином, щоб не виникала внутрішня кровотеча); крововтрати досягали шляхом виконання операційного доступу і пересікання стегнових судин в об'ємі від 20 до 22 \% об'єму циркулюючої крові тварини протягом 1 хв (гостра крововтрата), після чого кровотечу зупиняли, перев'язуючи судини.
Тваринам 3-ї дослідної групи (ГД-3) було змодельовано поєднану травму органів черевної порожнини, кровотечу таішемічно-реперсрузійний синдром відповідно до методик, описаних вище.

Тварин дослідних груп виводили з експерименту за умов тіопентал-натрієвого знеболювання (60 мг кг $^{-1}$ ) методом тотального кровопускання із серця через 1, 3 та 7 діб після реперфузії. Для дослідження забирали легені щурів.

У гомогенатах тканини легень визначали рівень каталази - ключового компонента фрерментативної ланки антиоксидантного захисту $[16,17]$ та рівень реагентів до тіобарбітурової кислоти (ТБК-активних продуктів), які належать до індикаторних показників інтенсивності пероксидного окиснення ліпідів [18]. На основі цих даних розраховували антиоксидантно-прооксидантний індекс (АПІ = активність каталази / вміст ТБК-активних продуктів ПОЛ). Він $є$ одним із чутливих індикаторів стану антиоксидантного захисту та відображає баланс між антиоксидантними і прооксидантними механізмами.

Досліджували зазначені показники в Центральній науковій лабораторії Тернопільського державного медичного університету імені І. Я. Горбачевського.

Достовірність відмінностей між контрольною і дослідними групами оцінювали з використанням непараметричного критерію Манна - Уїтні. Відмінності вважали істинними при вірогідності нульової гіпотези менше $5 \%(p<0,05)$.

РЕЗУЛЬТАТИ Й ОБГОВОРЕННЯ. У ГОМОгенатах тканини легень піддослідних тварин визначали рівень ТБК-активних продуктів ПОЛ. Результати дослідження наведено в таблиці 1. Встановлено, що він зростав у всіх групах: у ГД-1 через 1 добу достовірно $(p<0,05)$ перевищував контрольні показники на 140,2 \%, через 3 доби збільшувався відносно КГ на 152,9 \% ( $<<0,05)$, через 7 діб дещо зменшувався, однак достовірно перевищував контроль на 64,2 \% ( $<<0,05)$; у ГД-2 достовірно $(p<0,05)$ був більшим від контрольних показників протягом усього спостереження - на $225,4,257,5$ та 238,1 \% відповідно; у гД-3 достовірно $(p<0,05)$ перевищував контроль: на 399,3 \% - через 1 добу, на 558,2 \% - через 3 доби, на 634,3 \% - через 7 діб.

При аналізі рівня ТБК-активних продуктів ПОЛ у групах піддослідних тварин у контрольних точках дослідження встановлено, що через 1 добу після моделювання травми найменшим він був у ГД-1. У ГД-2 рівень ТБК-активних продуктів ПОЛ перевищував такий у ГД-1 на $35,4 \%\left(p_{1-2}<0,01\right)$, у ГД-3-на $107,8 \%\left(p_{1-3}<0,001\right)$. Також достовірну різницю $\left(\mathrm{p}_{2-3}<0,001\right)$ спостерігали між показниками цих продуктів у ГД-2 та 
Таблиця 1 - Рівень ТБК-активних продуктів пероксидного окиснення ліпідів у тканині легень (мкмоль/кг ${ }^{1}$ ) у динаміці реперфузії (Me (LQ; UQ) - медіана (нижній і верхній квартилі))

\begin{tabular}{|c|c|c|c|c|}
\hline \multirow{2}{*}{ Група дослідження } & \multirow{2}{*}{ КГ } & \multicolumn{3}{|c|}{ "Термін дослідження, доба } \\
\hline & & 1-ша & 3-тя & 7-мa \\
\hline ГД-1 & \multirow[t]{3}{*}{$\begin{array}{c}1,34 \\
(1,25 ; 1,37) \\
(n=10)\end{array}$} & $\begin{array}{c}3,22^{*} \\
(2,78 ; 3,38) \\
(n=8)\end{array}$ & $\begin{array}{c}3,39^{\star} \\
(2,98 ; 4,20) \\
(n=8)\end{array}$ & $\begin{array}{c}2,20^{*} \\
(2,02 ; 2,96) \\
(n=8)\end{array}$ \\
\hline ГД-2 & & $\begin{array}{c}4,36^{\star} \\
(4,29 ; 4,46) \\
(n=8)\end{array}$ & $\begin{array}{c}4,79^{\star} \\
(4,34 ; 4,95) \\
(n=7)\end{array}$ & $\begin{array}{c}4,53^{\star} \\
(4,05 ; 4,77) \\
(n=7)\end{array}$ \\
\hline ГД-3 & & $\begin{array}{c}6,69^{*} \\
(5,90 ; 6,94) \\
(n=7)\end{array}$ & $\begin{array}{c}8,82^{\star} \\
(8,48 ; 9,58) \\
(n=6)\end{array}$ & $\begin{array}{c}9,84^{\star} \\
(8,86 ; 10,29) \\
(n=6)\end{array}$ \\
\hline \multicolumn{2}{|c|}{$p_{1-2}$} & $<0,001$ & $<0,01$ & $<0,01$ \\
\hline \multicolumn{2}{|c|}{$p_{1-3}$} & $<0,001$ & $<0,001$ & $<0,001$ \\
\hline \multicolumn{2}{|c|}{$\mathrm{p}_{2-3}$} & $<0,001$ & $<0,001$ & $<0,001$ \\
\hline
\end{tabular}

Примітки. Тут і в таблицях 2, 3:

1. * - відмінності стосовно КГ статистично достовірні $(p<0,05)$.

2. $\mathrm{p}_{1-2}$ - достовірність відмінностей показника між ГД-1 та ГД-2.

3. $\mathrm{p}_{1-3}$ - достовірність відмінностей показника між ГД-1 та ГД-3.

4. $\mathrm{p}_{2-3}$ - достовірність відмінностей показника між ГД-2 та ГД-3.

ГД-3. Через 3 доби їх показник зростав у всіх групах піддослідних тварин. Найнижчий рівень відзначали, як і в попередній точці, у ГД-1. У цій групі рівень ТБК-активних продуктів ПОЛ був достовірно меншим, ніж у ГД-2 та ГД-3, - на $41,3 \%\left(\mathrm{p}_{1-2}<0,01\right)$ i $160,2 \%\left(\mathrm{p}_{1-3}<0,001\right)$ відповідно. Також достовірну різницю $\left(\mathrm{p}_{2-3}<0,001\right)$ спостерігали між показниками цих продуктів у ГД-2 та ГД-3. Через 7 діб їх рівень знижувався відносно попередніх показників у ГД-1 та ГД-2, у ГД-3 він зростав. Максимальний показник зафріксовано у ГД-3, він достовірно перевищував такий у ГД-1 та ГД-2 - на 347,3 \% $\left(p_{1-3}<0,001\right)$ і $117,2 \%$ $\left(p_{2-3}<0,001\right)$ відповідно. У ГД-2 рівень ТБК-активних продуктів ПОЛ був достовірно більшим, ніж у ГД-1, на $105,9 \%\left(\mathrm{p}_{1-2}<0,01\right)$.

Аналогічну тенденцію спостерігали в динаміці зміни показника каталази в групах піддослідних тварин (табл. 2). Так, через 1 добу після моделювання травми він достовірно зростав: у ГД-1 - в 4,5 раза $(p<0,05)$, у ГД-2 - в 7,2 раза $(p<0,05)$, у
ГД-3 - в 10,1 раза $(p<0,05)$. Через 3 доби рівень каталази у всіх групах піддослідних тварин був достовірно більшим $(p<0,05)$, ніж у КГ, - у 5,0, 8,1 та 5,9 раза відповідно. Через 7 діб у ГД-1 він незначно зростав і достовірно перевищував контрольні показники в 5,3 раза $(p<0,05)$. У ГД-2 та ГД-3 рівень каталази в ці терміни зменшувався і був більшим, ніж у КГ, відповідно, у 7,0 разів $(p<0,05)$ та 4,0 рази $(p<0,05)$.

При аналізі рівня каталази в групах піддослідних тварин у контрольних точках дослідження встановлено, що через 1 добу після моделювання травми найнижчим він був у ГД-1. У ГД-2 рівень каталази перевищував такий у ГД-1 на 60,8 \% $\left(p_{1-2}<0,01\right)$, у ГД-3-на $124,3 \%\left(p_{2-3}<0,001\right)$. Також достовірну різницю $\left(\mathrm{p}_{1-3}<0,001\right)$ спостерігали між ії показниками у ГД-1 таГД-3. Через 3 доби рівень каталази зростав у ГД-1 та ГД-2, в ГД-3 він зменшувався відносно попереднього показника. Найнижчий рівень відзначали, як і в попередній точці, у ГД-1. У цій групі він був достовірно мен-

Таблиця 2 - Рівень каталази у тканині легень (мккат· кг $^{-1}$ ) у динаміці реперфузії (Me (LQ; UQ) - медіана (нижній і верхній квартилі))

\begin{tabular}{|c|c|c|c|c|}
\hline \multirow{2}{*}{ Група дослідження } & \multirow{2}{*}{$\mathrm{K} \Gamma$} & \multicolumn{3}{|c|}{ Термін дослідження, доба } \\
\hline & & 1-ша & 3-тя & 7-ма \\
\hline ГД-1 & \multirow[t]{3}{*}{$\begin{array}{c}1,89 \\
(1,38 ; 2,01) \\
(n=10)\end{array}$} & $\begin{array}{c}8,52^{*} \\
(9,91 ; 8,91) \\
(n=8)\end{array}$ & $\begin{array}{c}9,60^{*} \\
(9,43 ; 10,72) \\
(n=8)\end{array}$ & $\begin{array}{c}10,10^{\star} \\
(9,58 ; 11,07) \\
(n=8)\end{array}$ \\
\hline ГД-2 & & $\begin{array}{c}13,70^{\star} \\
(12,22 ; 14,52) \\
(n=8)\end{array}$ & $\begin{array}{c}15,36^{\star} \\
(14,71 ; 16,07) \\
(n=7)\end{array}$ & $\begin{array}{c}13,26^{*} \\
(12,18 ; 15,28) \\
(n=7)\end{array}$ \\
\hline ГД-3 & & $\begin{array}{c}19,11^{*} \\
(17,97 ; 20,12) \\
(n=7)\end{array}$ & $\begin{array}{c}11,26^{*} \\
(10,51 ; 12,09) \\
(n=6)\end{array}$ & $\begin{array}{c}7,60^{*} \\
(7,04 ; 7,89) \\
(n=6)\end{array}$ \\
\hline \multicolumn{2}{|c|}{$p_{1-2}$} & $<0,01$ & $<0,001$ & $<0,01$ \\
\hline \multicolumn{2}{|c|}{$p_{1-3}$} & $<0,001$ & $<0,05$ & $<0,001$ \\
\hline \multicolumn{2}{|c|}{$\mathrm{p}_{2-3}$} & $<0,001$ & $<0,01$ & $<0,001$ \\
\hline
\end{tabular}


шим, ніж у ГД-2 та ГД-3, - на 60,0 \% ( $\left.p_{1-2}<0,001\right)$ і 17,3\% $\left(p_{1-3}<0,05\right)$ відповідно. Також достовірну різницю $\left(\mathrm{p}_{2-3}<0,01\right)$ спостерігали між показниками каталази у ГД-2 та ГД-3. Через 7 діб ії рівень знижувався відносно попередніх показників у ГД-2 та ГД-3, у ГД-1 він незначно зростав. Максимальний показник зафіксовано у ГД-2, він достовірно перевищував такий у ГД-1 та ГД-3 на 31,3\% ( $\left.p_{1-2}<0,01\right)$ і 74,5\% $\left(p_{2-3}<0,001\right)$ відповідно. УГД-3 рівень каталази був достовірно меншим, ніж у ГД-1, на 32,9 \% ( $\left.p_{1-3}<0,001\right)$.

Зміни рівня ТБК-активних продуктів ПОЛ і каталази вплинули на величину АПІ у групах піддослідних тварин (табл. 3). У ГД-1 через 1 добу АПІ достовірно $(p<0,05)$ перевищував контрольні показники на 86,4 \%, через 3 доби він зростав відносно КГ на 102,7 \% (p<0,05), через 7 діб збільшувався та достовірно перевищував контроль на 221,1 \% (p<0,05). У ГД-2 АП। достовірно $(p<0,05)$ перевищував контрольні показники протягом усього спостереження - на 119,1, 118,4 та 108,2 \% відповідно. У ГД-3 через 1 добу він достовірно ( $<<0,05)$ був більшим, порівняно з КГ, на 114,9 \%, у подальшому достовірно меншим $(\mathrm{p}<0,05)$ від контролю: через 3 доби - на 17,1 \%, через 7 діб - на 46,9 \%.

При аналізі АПІ в групах піддослідних тварин у контрольних точках дослідження встановлено, що через 1 добу після моделювання травми найменшим він був у ГД-1. У ГД-2 його рівень перевищував такий у ГД-1 на 17,5 \% ( $\left.p_{1-2}>0,05\right)$, у ГД-3 - на 1,8 \% ( $\left.p_{1-3}>0,05\right)$. Достовірної різниці між показниками АПІ у ГД-1 та ГД-3 не спостерігали. Через 3 доби у ГД-1 та ГД-2 він збільшувався, у ГД-3 - зменшувався. Найнижчий АПІ зафріксовано в ГД-3, він був меншим, ніж у ГД-1 та ГД-2, на 59,1 \% ( $\left.p_{1-3}<0,01\right)$ і 61,9\% $\left(p_{2-3}<0,01\right)$ відповідно. Достовірної різниці між його показниками у ГД-1 та ГД-2 не спостерігали.

Через 7 діб АПІ знижувався відносно попередніх показників у ГД-2 та ГД-3, в ГД-1 його рівень зростав. Максимальний показник зафіксовано у ГД-1, він достовірно перевищував такий у ГД-2 та ГД-3 - на 54,2 \% ( $\left.p_{1-2}<0,05\right)$ і 505,1 \% $\left(p_{1-3}<0,001\right)$ відповідно. У ГД-2 АПІ був достовірно більшим, ніж у ГД-3, на 292,3 \% ( $\left.p_{2-3}<0,001\right)$.

Як відомо, величина АПІ вказує на наявний баланс прооксидантної та антиоксидантної систем в організмі. Як свідчать отримані результати, в усіх групах піддослідних тварин був наявний дисбаланс, який тривав до кінця експерименту. В ГД-1 даний показник вказував на значну активацію протиоксидантної системи і тривале напруження адаптаційно-компенсаторних механізмів. Безперечно, це спрямовано на усунення патологічних чинників, які виникають внаслідок реперсузії значної маси м'язової тканини. Звертають на себе увагу значні зміни у групі піддослідних тварин, в яких реперфузія поєднувалась із масивною крововтратою та закритою травмою органів черевної порожнини. У них спостерігали процес значного і тривалого оксидативного стресу. Також, з огляду на зниження АПІ до кінця експерименту, можна говорити про виснаження механізмів, відповідальних за антиоксидантний захист, і зростання процесів ПОЛ. У свою чергу, надмірна тривала активація системи ПОЛ є пусковим фрактором розвитку системної відповіді на запалення та поліорганної недостатності.

Таким чином, результати аналізу змін системи пероксидного окиснення ліпідів у групах дослідження свідчать про те, що накладання кровоспинних джгутів на обидві нижні кінцівки піддослідних тварин викликало значну активацію системи ПОЛ протягом 7-ми днів після моделювання травми. Слід зазначити, що термін накладання становив 2 год. Цей час вважають безпечним з точки зору розвитку місцевих ускладнень. Встановлено, що динаміка змін показників каталази і ТБК-активних продуктів ПОЛ до кінця 7-ї доби мала позитивний характер, зважаючи

Таблиця 3 - Вплив реперфузії кінцівки на величину антиоксидантно-прооксидантного індексу у тканині легень (ум. од.) (Me (LQ; UQ) - медіана (нижній і верхній квартилі))

\begin{tabular}{|c|c|c|c|c|}
\hline \multirow{2}{*}{ Група дослідження } & \multirow{2}{*}{ КГ } & \multicolumn{3}{|c|}{ Термін дослідження, доба } \\
\hline & & 1-ша & 3-тя & 7-ма \\
\hline ГД-1 & \multirow{6}{*}{$\begin{array}{c}1,47 \\
(1,01 ; 1,62) \\
(n=10)\end{array}$} & $2,74^{*}$ & $2,98^{*}$ & $4,72^{*}$ \\
\hline & & $\begin{array}{c}(2,31 ; 3,12) \\
(n=8)\end{array}$ & $\begin{array}{c}(2,49 ; 3,17) \\
(n=8)\end{array}$ & $\begin{array}{c}(3,50 ; 5,34) \\
(n=8)\end{array}$ \\
\hline ГД-2 & & $3,22^{*}$ & $3,21^{*}$ & $3,06^{*}$ \\
\hline & & $\begin{array}{c}(2,72 ; 3,50) \\
(n=8)\end{array}$ & $\begin{array}{c}(3,02 ; 3,35) \\
(n=7)\end{array}$ & $\begin{array}{c}(2,56 ; 3,57) \\
(n=7)\end{array}$ \\
\hline ГД-3 & & $3,16^{*}$ & $1,22^{*}$ & $0,78^{\star *}$ \\
\hline & & $\begin{array}{c}(2,72 ; 3,30) \\
(n=7)\end{array}$ & $\begin{array}{c}(1,18 ; 1,24) \\
(n=6)\end{array}$ & $\begin{array}{c}(0,74 ; 0,84) \\
(n=6)\end{array}$ \\
\hline \multicolumn{2}{|c|}{$p_{1-2}$} & $>0,05$ & $>0,05$ & $<0,05$ \\
\hline \multicolumn{2}{|c|}{$p_{1-3}$} & $>0,05$ & $<0,01$ & $<0,001$ \\
\hline \multicolumn{2}{|c|}{$p_{2-3}$} & $>0,05$ & $<0,01$ & $<0,001$ \\
\hline
\end{tabular}


на зменшення їх рівня. Також, з огляду на нульовий рівень загибелі піддослідних тварин та відсутність місцевих ускладнень, виявлені зміни мали компенсаторний характер, що підтверджено і в інших дослідженнях $[18,19]$. Також виявлено, що зміни показників системи ПОЛ у ГД-1 та ГД-2 були схожими за своєю динамікою, хоча достовірно відрізнялися в контрольних точках спостереження. Це дає змогу припустити, що в організмі піддослідних тварин відсутні стійкі адаптаційні механізми у відповідь на реперфузію. Таким чином, можна вважати, що при поєднанні 3 іншими травмами реперсузія може мати потенціювальний характер щодо розвитку системних змін. Це підтверджують зміни в системі ПОЛ у групі піддослідних тварин, в яких реперфузія поєднувалась із масивною зовнішньою крововтратою та закритою травмою органів черевної порожнини. У цій групі показники каталази і ТБКактивних продуктів ПОЛ різко зростали до кінця 7-ї доби відносно як контролю, так і ГД-1 та ГД-2.

Проаналізувавши зміни показника каталази у групах піддослідних тварин, можна зробити висновокпро значну активацію системи антиоксидантного захисту у відповідь на змодельовану травму. Звертає на себе увагу динаміка змін рівня каталази у ГД-3. Його різке зниження після 1-ї доби спостереження свідчить про виснаження системи антиоксидантного захисту та прогресування системних патологічних змін.

Слід зауважити, що величина АПІ, яка відображає баланс прооксидантних і антиоксидантних механізмів, до 7-ї доби не нормалізувалася в ГД-1. Це підтверджує припущення про

\section{СПИСОК ЛІТЕРАТУРИ}

1. Deaths: Final data for 2014 / K. D. Kochanek, S. L. Murphy, J. Xu, B. Tejada-Vera // Natl. Vital. Stat. Rep. - 2016. - No. 65. - P. 1-122.

2. An analysis of prehospital deaths: Who can we save? / J. S. Davis, S. S. Satahoo, F. K. Butler [et al.] // J. Trauma Acute Care Surg. - 2014. - No. 77. - P. 213218.

3. Cannon J. W. Hemorrhagic shock / J. W. Cannon // N. Engl. J. Med. - 2018. - 378 (4). - P. 370-379.

4. New effective tourniquets for potential use in the military environment: A serving soldier study / A. Beaven, R. Briard, M. Ballard, P. Parker // Military Medicine. 2017. - 182 (7). - P. 1929-1932.

5. Телев'як А. Т. Динаміка показників перекисного окиснення ліпідів та антиоксидантного захисту в м'язовій тканині задніх кінцівок щурів при розвитку ішемічно-реперсузійного синдрому / А. Т. Телев'як // Здобутки клініч. і експерим. медицини. -2018. - № 3. С. 132-139. те, що накладання кровоспинного джгута, навіть протягом безпечного періоду, викликає тривалі системні зміни в організмі й тривале напруження адаптаційно-компенсаторних механізмів, спрямованих на усунення патогенних чинників. Також, як показали результати дослідження, поєднання закритої травми органів черевної порожнини з геморагічним шоком та реперфузією кінцівки призводить до виникнення тривалого оксидативного стресу, а зниження АПІ - до виснаження антиоксидантних механізмів. Відомо, що інтенсифікація процесів ПОЛ є одним із пускових механізмів системної відповіді організму на запалення, що, у свою чергу, значно збільшує ймовірність розвитку поліорганної недостатності.

ВИСНОВКИ. 1. Репердузія нижніх кінцівок викликає тривалу активацію системи ліпідної пероксидації, що підтверджується статистично достовірним $(p<0,05)$ зростанням вмісту ТБКактивних продуктів ПОЛ у ГД-1 з максимумом через 3 доби.

2. Реперфузія нижніх кінцівок внаслідок двогодинного накладання джгутів у поєднанні 3 травмою органів черевної порожнини та масивною зовнішньою крововтратою спричиняє найбільш значиме порушення балансу антиоксидантно-прооксидантних процесів порівняно 3 іншими типами травм.

Перспективи подальших досліджень. У перспективі передбачається розробити патогенетично обґрунтовані засоби корекції системних змін, що виникають під впливом реперфузії кінцівки.

6. Сергеевич Р. А. Полиорганная недостаточность при тяжелой сочетанной травме: структура и прогноз формирования / Р. А. Сергеевич, Е. В. Григорьев // Медицина в Кузбасе. - 2016. - 15, № 1. - С. 90-98.

7. Lenz A. Systemic inflametion after trauma / A. Lenz, G. A. Franrlin, W. G. Cheadle // Injury. -2007. 38 (12). - P. 1336-1345.

8. Fujishima S. Pathophisiology and biomarkers of acute respiratory distress syndrome / S. Fujishima // Jornal of Intensive Care. - 2014. - 2 (1). - P. 32-38.

9. Acute respiratory distress syndrome: the Berlin definition / V. M. Ranieri, G. D. Rubenfeld, B. T. Thompson [et al.] // JAMA. - 2012. - No. 307. - P. 2526-2533.

10. Risk factors for the development of acute respiratory distress syndrome following hemorrhage / B. R. Robinson, M. J. Cohen, J. B. Holcomb [et al.] // Shock. - 2018. - No. 50. - P. 258-264.

11. Incidence, risk factors, and mortality associated with acute respiratory distress syndrome in combat 
casualty care / P. K. Park, J. W. Cannon, W. Ye. [et al.] // J. Trauma Acute Care Surg. - 2016. - No. 81. - P. 156.

12. Association between age and acute respiratory distress syndrome development and mortality following trauma / E. Y. Killien, B. Mills, M. S. Vavilala [et al.] // Journal of Trauma and Acute Care Surgery. - 2019. 86 (5). - P. 844-852.

13. Stevens J. P. Acute respiratory distress syndrome / J. P. Stevens, A. Law, J. Giannakoulis // JAMA. 2018. - 319 (7). - P. 732.

14. Fracture energy threshold in parry injuries due to sharp and blunt force / S. Gentile, B. P. Kneubuehl, V. Barrera [et al.] // Int. J. Legal Med. - 2019. - 133 (5). P. 1429-1435.

15. Evaluation of the clinical effect of small-volume resuscitation on uncontrolled hemorrhagic shock in emergency / G. Zhao, W. Wu, Q. M. Feng [et al.] // Ther. Clin. Risk Manag. - 2017. - No. 13. - P. 387-392.

\section{REFERENCES}

1. Kochanek, K.D., Murphy, S.L., Xu, J., \& TejadaVera, B. (2016). Deaths: Final data for 2014. Natl. Vital. Stat. Rep., 65, 1-122.

2. Davis, J.S., Satahoo, S.S., Butler, F.K., Dermer, H., Naranjo, D., Julien, K., ..., \& Schulman, C.I. (2014). An analysis of prehospital deaths: Who can we save? J. Trauma Acute Care Surg., 77, 213-218.

3. Cannon, J.W. (2018). Hemorrhagic shock. N. Engl. J. Med., 378 (4), 370-379.

4. Beaven, A., Briard, R., Ballard, M., \& Parker, P. (2017). New effective tourniquets for potential use in the military environment: A serving soldier study. Military Medicine, 182 (7), 1929-1932.

5. Televiak, A.T. (2018). Dynamika pokaznykiv perekysnoho okysnennia lipidiv ta antyoksydantnoho zakhystu v miazovii tkanyni zadnikh kintsivok shchuriv pry rozvytku ishemichno-reperfuziinoho syndromu [The dynamic of indicators of lipid peroxidation and antioxidant protection in muscle tissue of the hind limbs of the rats in development of the ischemic-reperfusion syndrome (experimental study)]. Zdobutky klinichnoi i eksperymentalnoi medytsyny - Achievements of Clinical and Experimental Medicine, 3, 132-139 [in Ukrainian].

6. Sergeyevich, R.A., \& Grigoryev, Ye.V. (2016). Poliorgannaya nedostatochnost prityazheloy sochetannoy travme: struktura i prognoz formirovaniya [Multiple organ failure in severe concomitant injury: structure and formation prognosis]. Meditsina $v$ Kuzbase - Medicine in Kuzbass, 15, 1, 90-98 [in Russian].

7. Lenz, A., Franrlin, G.A., \& Cheadle, W.G. (2007). Systemic inflametion after trauma. Injury, 38 (12), 13361345.

8. Fujishima, S. (2014). Pathophisiology and biomarkers of acute respiratory distress syndrome. Jornal of Intensive Care, 2 (1), 32-38.

9. Ranieri, V.M., Rubenfeld, G.D., Thompson, B.T., Ferguson, N.D., Caldwell, E., Fan, E., ..., Slutsky, A.S. (2012). Acute respiratory distress syndrome: the Berlin definition. JAMA, 307, 2526-2533.
16. Нагорная Н. В. Оксидативный стресс: влияние на организм человека, методы оценки / Н. В. Нагорная, Н. А. Четверик [Электронный ресурс] // Здоров'я дитини. - 2010. - № 2. - Режим доступа : http://www. mif-ua.com/archive/article/12762.

17. Метод определения активности каталазы / М. А. Королюк, Л. И. Иванова, И. Г. Майорова, В. Е. Токарев // Лаб. дело. - 1988. - № 1. - С. 16-19.

18. Del Rio D. A review of recent studies on malondialdehyde as toxic molecule and biological marker of oxidative stress / D. Del Rio, A. J. Stewart, N. Pellegrini // Nutr. Metab. Cardiovasc. Dis. -2005. - 15. - P. 316-328.

19. Volotovska N. V. Changes in the glutathione systems activity of internal organs in the first hours of experimental limb ischemia-reperfusion syndrome, combined with blood loss and mechanical injury / N. V. Volotovska, T. C. Nhokwara, I. V. Zhulkevych // Здобутки клініч. і експерим. медицини. - 2019. - № 1. C. 23-27.

10. Robinson, B.R.H., Cohen, M.J., Holcomb, J.B., Pritts, T.A., Gomaa, D., Fox, E.E., ..., Bulger, E.M. (2018). Risk factors for the development of acute respiratory distress syndrome following hemorrhage. Shock, 50, 258-264.

11. Park, P., Cannon, J., Ye, W., Blackbourne, L., Holcomb, J., Beninati, W., \& Napolitano, L. (2016). Incidence, risk factors, and mortality associated with acute respiratory distress syndrome in combat casualty care. J. Trauma Acute Care Surg., 81, 156.

12. Killien, E.Y., Mills, B., Vavilala, M.S., Watson, R.S., O'Keefe, G.E., \& Rivara, F.P. (2019). Association between age and acute respiratory distress syndrome development and mortality following trauma. Journal of Trauma and Acute Care Surgery, 86 (5), 844-852.

13. Stevens, J.P., Law, A., \& Giannakoulis, J. (2018). Acute Respiratory Distress Syndrome. JAMA, 319 (7), 732.

14. Gentile, S., Kneubuehl, B.P., Barrera, V., Dobay, A., Thali, M.J., \& Bolliger, S.A. (2019). Fracture energy threshold in parry injuries due to sharp and blunt force. Int. J. Legal Med., 133 (5), 1429-1435.

15. Zhao, G., Wu, W., Feng, Q.M., \& Sun, J. (2017). Evaluation of the clinical effect of small-volume resuscitation on uncontrolled hemorrhagic shock in emergency. Ther. Clin Risk Manag., 13, 387-392.

16. Nagornaya, N.V., \& Chetverik, N.A. (2010). Oksidativnyy stress: vliyaniye na organizm cheloveka, metody otsenki [Oxidative stress: effect on the human body, assessment methods]. Zdorovia dytyny - Child's Health, 2. Retrieved from: http://www.mif-ua.com/archive/ article/12762 [in Russian].

17. Korolyuk, M.A., Ivanova, L.I., Mayorova, I.G., \& Tokarev, V.Ye. (1988). Metod opredeleniia aktivnosti katalazy [A method of determining catalase activity]. Laboratornoye delo - Laboratory Matter, 1, 16-19 [in Russian].

18. Del Rio, D., Stewart, A.J., \& Pellegrini, N. (2005). A review of recent studies on malondialdehyde as toxic 
molecule and biological marker of oxidative stress. Nutr. Metab. Cardiovasc. Dis., 15, 316-328.

19. Volotovska, N.V., Nhokwara, T.C., \& Zhulkevych, I.V. (2019). Changes in the glutathione systems activity of internal organs in the first hours of experimental limb ischemia-reperfusion syndrome, combined with blood loss and mechanical injury. Zdobutky klinichnoi i eksperymentalnoi medytsyny-Achievements of Clinical and Experimental Medicine, 1, 23-27.

О. В. Федосеева

\section{ИЗМЕНЕНИЯ ПОКАЗАТЕЛЕЙ АНТИОКСИДАНТНО-ПРООКСИДАНТНОЙ СИСТЕМЫ В ТКАНИ ЛЕГКИХ В УСЛОВИЯХ ТРАВМЫ ОРГАНОВ БРЮШНОЙ ПОЛОСТИ, ГИПОВОЛЕМИЧЕСКОГО ШОКА И РЕПЕРФУЗИИ НИЖНИХ КОНЕЧНОСТЕЙ В ЭКСПЕРИМЕНТЕ}

\section{Резюме}

Вступление. В статье приведены результаты экспериментального исследования, во время которого изучали влияние реперфузии нижних конечностей на изменения показателей антиоксидантнопрооксидантной системы в ткани легких при закрытой травме органов брюшной полости и массивной наружной кровопотере. Они показали, что реперфузия нижних конечностей в сочетании с моделируемыми травмами вызывает значительную активацию системы перекисного окисления липидов в течение 7-ми дней посттравматического периода.

Цель исследования - изучить изменения антиоксидантно-прооксидантной системы в ткани легких на модели сочетанной травмы органов брюшной полости, гиповолемического шока и реперфузии нижних конечностей.

Методы исследования. Эксперимент проведен на 80-ти нелинейных крысах-самцах массой 190-220 2. В исследовательских группах была смоделирована реперфузия нижних конечностей в сочетании с закрытой травмой органов брюшной полости на фроне массивной кровопотери и проанализирована динамика изменений показателей ТБК-активных продуктов и каталазы. На основе этих данных рассчитывали антиоксидантно-прооксидантный индекс. Достоверность различий между контрольной и исследовательскими группами оценивали с использованием непараметрического критерия Манна - Уитни.

Результаты и обсуждение. Результаты анализа изменений системы перекисного окисления липидов в исследовательских группах свидетельствуют о том, что наложение кровоостанавливающих жгутов на обе нижние конечности подопытных животных вызвало значительную активацию этой системы в течение 7-ми дней после моделирования травмы. Сочетание закрытой травмы органов брюшной полости с массивной кровопотерей и реперфузией конечности привело к возникновению длительного оксидативного стресса, а снижение антиоксидантно-прооксидантного индекса - к истощению антиоксидантных механизмов.

Вывод. Наложение кровоостанавливающих жгутов на две нижние конечности на 2 ч вызывает длительную активацию системы липидной пероксидации, что подтверждается статистически достоверным $(p<0,05)$ увеличением содержания ТБК-активных продуктов перекисного окисления липидов с максимумом через 3 суток.

КЛЮЧЕВЫЕ СЛОВА: реперфузия; эксперимент; легкие; перекисное окисление липидов; сочетанная травма; массивная кровопотеря. 


\title{
CHANGES IN THE INDICATORS OF THE ANTIOXIDANT-PROOXIDANT SYSTEM IN THE LUNG TISSUES IN CASE OF THE ABDOMINAL TRAUMA, HYPOVOLEMIC SHOCK AND REPERFUSION OF LOWER LIMBS IN THE EXPERIMENT
}

\begin{abstract}
Summary
Introduction. The article presents the results of an experimental study that examined the effect of lower extremity reperfusion on changes in the antioxidant-prooxidant system in lung tissues under conditions of closed abdominal trauma and massive external blood loss. The results of the study showed that reperfusion of the lower extremities in combination with the simulated traumas caused a significant activation of the antioxidant-prooxidant system within seven days after the traumatic period.

The aim of the study - to study changes in the antioxidant-prooxidant system in lung tissue in a model of combined abdominal trauma, hypovolemic shock, and lower extremity reperfusion.

Research Methods. An experiment was conducted on 80 non-linear male rats weighing 190-220 grams. In the experimental groups, reperfusion of the lower extremities in combination with closed trauma of the abdominal organs was simulated against the background of massive blood loss and the dynamics of changes in the indices of TBA-active products and catalase were analyzed. Based on these data, an antioxidant-prooxidant index was calculated. The likelihood of differences between the control group and the study group was evaluated using the non-parametric Mann-Whitney test.
\end{abstract}

Results and Discussion. After analyzing changes in the lipid peroxidation system in the study groups, we obtained results indicating that the imposition of hemostatic bundles on both lower extremities of the experimental animals caused significant activation of the LPO system within seven days after trauma modeling. Also, as the results of the study showed, the combination of closed abdominal trauma with massive blood loss and limb reperfusion leads to long-term oxidative stress on the one hand, and a decrease in AP I indicates a depletion of antioxidant mechanisms.

Conclusion. The imposition of hemostatic bundles on the two lower extremities, for two hours, causes a prolonged activation of the lipid peroxidation system, which is confirmed by statistically significant $(p<0.05)$ increase in the content of TBA-active LPO products, with a maximum after 3 days. loss.

KEY WORDS: reperfusion; experiment; lungs; lipids peroxidation; combined trauma; massive blood

Отримано 17.01.20

Адреса для листування: О. В. Федосєєва, Український науково-практичний чентр екстреної медичної допомоги та медицини катастрофр МОЗ України, вул. Братиславська, 3, Київ, 02166, Україна, e-mail: fedoseevaov@ukr.net. 